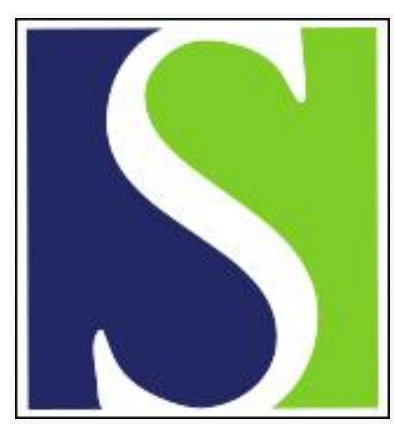

Scand J Work Environ Health 1996;22(1):14-26

https://doi.org/10.5271/sjweh.104

Issue date: Feb 1996

Incidence and risk factors of cancer among men and women in Norwegian agriculture

by Kristensen P, Andersen A, Irgens LM, Laake P, Bye AS

The following articles refer to this text: $2002 ; 28(4): 270-277$;

2004;30(3):215-222; 2004;30(5):356-361; 2007;33(5):325-335;

2008;34(1):73-79; 2016;42(2):144-152

Key terms: animal husbandry; cohort study; farming; leukemia; life-style; multiple myeloma; neoplasm; pesticide

This article in PubMed: www.ncbi.nlm.nih.gov/pubmed/8685669 


\title{
Incidence and risk factors of cancer among men and women in Norwegian agriculture
}

\author{
by Petter Kristensen, MD, ${ }^{1}$ Aage Andersen, ${ }^{2}$ Lorentz M Irgens, MD, ${ }^{3}$ Petter Laake, PhD, ${ }^{4}$ Anne S Bye ${ }^{5}$
}

\begin{abstract}
Kristensen P, Andersen A, Irgens LM, Laake P, Bye AS. Incidence and risk factors of cancer among men and women in Norwegian agriculture. Scand J Work Environ Health 1996;22:14-26.

Objectives The objective of the study was to examine cancer incidence and identify risk factors among subjects born in 1925-1971 and engaged in agricultural activities in Norway.

Methods A cohort was established through linkage between agricultural censuses in 1969-1989 and the Central Population Register, which identifies farm holders and their spouses. Available census information on the activity of the farm provided the exposure indicators. Incident cancer in 1969-1991 was identified in the Cancer Register. In an analysis for standardized incidence ratios (SIR), the cohort was compared with the total rural population of Norway. Associations with exposure indicators were investigated in a Poisson regression analysis.

Results In the follow-up of 136463 men for 1.5 million person-years and 109641 women for 0.6 million person-years, 3333 and 2145 cancer cases were identified, respectively. The subset defined as farmers had an SIR of 77 [95\% confidence interval (95\% CI) 73-81] for the men and 92 (95\% CI 85-99) for the women, with particularly low SIR values for lung cancer and other sites linked to life-style. The several positive associations found confirmed the a priori hypothesis of an association between dairy farming and acute leukemia among men [rate ratio 1.76, 95\% CI 1.02-3.05]. Multiple myeloma was associated with pesticide indicators for both genders, mainly for subjects cultivating potatoes.

Conclusions The results support the hypothesis of a relationship between acute leukemia and animal contact and between multiple myeloma and pesticides in potato cultivation. Other exposure associations, especially for cancer among women, warrant further investigation.
\end{abstract}

Key terms animal husbandry, cohort study, farming, leukemia, life-style, multiple myeloma, neoplasm, pesticide.

Cancer among male farmers and agricultural workers has been extensively studied and reviewed $(1-4)$. In most studies, the total cancer incidence has been about $20 \%$ lower than that of the general population, mainly due to a low risk for lung cancer, but also due to moderately low risks for cancer of the esophagus, colon, liver, kidney, and bladder (4). In a meta-analysis (4) a doubled risk was found for lip cancer. Small (5-20\%) but significant excess risks were also found for cancer of the ventricle and prostate, malignant melanoma, multiple myeloma, Hodgkin's disease, and leukemia (4).

Only few studies have been performed on cancer among women in farming and agriculture (5-9). The results give no clear indications of deviances from expected cancer risks, except for low incidences of lung cancer and breast cancer (9). Mortality data for Norway show that male farm managers have a total mortality that is about $20 \%$ lower than that for all economically active men in 1970-1980, primarily due to low lung cancer mortality (10). Females engaged in farming (managers and workers) have only a slightly lower mortality than all economically active women (10).

Cancer occurrence among men in agricultural work resembles that found in rural populations in several countries, with low incidence mainly concentrated in sites where life-style risk factors have been verified (11). The lip and eye are the only sites of cancer with a consistent increase in rural rates as compared with urban rates (11).

No exposure-outcome association has firmly been established as causal, but the following three potential

1 National Institute of Occupational Health, Oslo, Norway.

2 Cancer Registry of Norway, Oslo, Norway.

3 Medical Birth Registry of Norway, Bergen, Norway.

4 Department of Medical Statistics, University of Oslo, Oslo, Norway.

5 Statistics Norway, Kongsvinger, Norway.

Reprint requests to: Dr Petter Kristensen, National Institute of Occupational Health, POB 8149 Dep, N-0033 Oslo, Norway. 
groups of risk factors and mechanisms of carcinogenicity have been proposed: carcinogenic effects of agrochemicals, in particular pesticides; animal viruses; and increased cancer risk due to immunologic perturbations of an unknown nature, caused by organic dust, pesticides, or other agents $(2,4)$.

Nine percent of the total work force was involved in agricultural activities in Norway in 1970 (12). The holdings are mainly small and medium-sized family farms without employed workers; only $10 \%$ of the total agricultural work force in the 1970 population census were employees (12). The numbers of farms and farmers have declined markedly during the last few decades, but agricultural production has been stable.

In Norway, multiregister linkage is possible due to the unique identification number assigned to all residents of Norway. Through linkage between data from the agricultural censuses in 1969-1989, the Central Population Register, and the Norwegian cancer register a cohort of farm holders in Norway and their families was established. We anticipated that the total and site-specific cancer pattern resembled the one found for farmers and agricultural workers in other countries.

Associations that have been repeatedly, although not consistently, found earlier formed the basis of our following hypotheses concerning relationships between indicators of different occupational exposures and cancer: (i) acute leukemia has been associated with farm exposures to animals, in particular dairy cows and poultry $(3,13)$; (ii) soft tissue sarcoma and non-Hodgkin's lymphoma have been connected with pesticide exposures, in particular herbicides in forestry and grain farming (3); (iii) acute leukemia (3), multiple myeloma $(3,14)$, lymphoma $(3,15,16)$, soft-tissue sarcoma (3), and brain tumor (3) are suspected to be caused by insecticides and other pesticides commonly used in horticulture; (iv) lymphoma $(2,17)$ and soft-tissue sarcoma (2) have been associated with livestock animals; and (v) brain tumors may be linked to Toxoplasma gondii through animal (pig, poultry) infection $(18,19)$.

For melanoma and nonmelanoma skin cancer, eye cancer, and lip cancer, we specifically searched for associations with types of farming related to much sun exposure and outdoor life $(3,11)$.

The risk-factor investigation was to some extent exploratory, especially for cancers among women, for whom few studies are available.

\section{Subjects and methods}

\section{Cohort}

The national agricultural censuses held by Statistics Norway have provided computerized file information since
1969 , and therefore it was possible to identify the majority of individuals engaged in agricultural work. We used data from the agricultural censuses made in 1969, 1979, and 1989, and the horticultural censuses made in 1974 and 1985. The criteria for participation in the different censuses have changed. The 1969 census included all farm holdings with an agricultural area of at least 0.5 ha. The 1979 and 1989 censuses were combined agriculture and forestry censuses and included farm holdings with at least 2.5 ha of productive forest area and farms which met minimum criteria on livestock size, area of cultivation of grain, vegetables, or berries, area of greenhouses, or number of fruit trees. Participation in the horticultural censuses depended on area of greenhouses, field-grown vegetables or berries, or number of fruit trees.

All persons who were personal holders at the time of any of the censuses and who were born later than 1924 were identified by means of their personal identification number; there was a total of 149254 individual holders (125873 men, 23381 women). The cohort was originally designed for a study of offspring of farmers, and therefore the restriction to subjects born after 1924 .

In record linkage between the file of holders and the Central Population Register 104370 spouses (13 802 men, 90568 women) and their children were identified. The Central Population Register was established in 1964 and is based on information from all residents of Norway at the time of the 1960 population census with continuous updating since 1964 (20). Divorced or dead spouses were not identified for certain by the linking procedure in the current version of the population register. However, we were able to trace all spouses from 1986 or later from historical files in the register.

\section{Cancer follow-up}

The resulting file of holders and spouses was linked to the Norwegian cancer register in which incident cancers including the site code of the International Classification of Diseases (seventh revision) (21), morphology (22), and date of diagnosis were identified. The cancer register receives reports on all new cases of cancer and benign tumors of the central nervous system. Case reporting has been mandatory since 1952 and is considered to be complete (23).

Cancer sites were also classified according to some known etiologic life-style factors. We defined cancers of the oral cavity, esophagus, and liver as alcohol-related (24) and cancers of the pancreas, larynx, lung, and bladder as tobacco-related (25).

The holders were followed for incident cancer from the agricultural census year when they were first identified. Spouses were followed from the year of complete identification (1986), or from 1989 if this was the start of the follow-up for the corresponding holder. Spouses born 
before 1925 and subjects only contributing person-time before the age of 20 years were excluded. Follow-up for all subjects continued through 1991, or until death or emigration. Altogether 7520 identified subjects were excluded due to birth before 1925 (spouses), birth after 1971, or death before the start of the follow-up (spouses); the remaining 136463 men and 109641 women contributed person-time. Descriptive characteristics of the cohort are provided in table 1. Most of the men (91\%) contributing person-time were farm holders,

Table 1. Descriptive characteristics for the men $(N=136463$, 1515482 person-years) and women ( $N=109641,598342$ person-years) engaged in agriculture according to the Norwegian agricultural censuses, 1969-1989.

\begin{tabular}{|c|c|c|}
\hline Characteristic & Men $(\%)$ & Women (\%) \\
\hline \multicolumn{3}{|l|}{ Year of birth } \\
\hline $\begin{array}{l}1925-1939 \\
1940-1949 \\
1950-1971\end{array}$ & $\begin{array}{l}45.8 \\
30.0 \\
24.2\end{array}$ & $\begin{array}{l}36.6 \\
34.0 \\
29.4\end{array}$ \\
\hline \multicolumn{3}{|l|}{ Year of entry of follow-up } \\
\hline $\begin{array}{l}1969 \\
1974 \\
1979 \\
1985 \\
1986 \\
1989\end{array}$ & $\begin{array}{r}23.2 \\
1.1 \\
35.5 \\
1.0 \\
3.2 \\
36.0\end{array}$ & $\begin{array}{r}0.8 \\
0.1 \\
7.5 \\
0.2 \\
54.0 \\
37.5\end{array}$ \\
\hline \multicolumn{3}{|l|}{ Age for entry of follow-up } \\
\hline $\begin{array}{l}20-29 \text { years } \\
30-39 \text { years } \\
\geq 40 \text { years }\end{array}$ & $\begin{array}{l}14.6 \\
38.4 \\
47.0\end{array}$ & $\begin{array}{r}9.3 \\
28.2 \\
62.4\end{array}$ \\
\hline \multicolumn{3}{|l|}{ Annual work input on the farm holding ${ }^{\mathrm{a}}$} \\
\hline $\begin{array}{l}0-499 h \\
500-999 h \\
\geq 1000 h\end{array}$ & $\begin{array}{l}47.7 \\
17.9 \\
34.4\end{array}$ & $\begin{array}{l}69.9 \\
18.4 \\
11.7\end{array}$ \\
\hline \multicolumn{3}{|l|}{ Municipality } \\
\hline $\begin{array}{l}\text { Urban } \\
\text { Rural, agriculture main industry } \\
\text { Other rural municipalities }\end{array}$ & $\begin{array}{l}11.2 \\
24.3 \\
64.5\end{array}$ & $\begin{array}{l}11.5 \\
23.9 \\
64.7\end{array}$ \\
\hline \multicolumn{3}{|l|}{ Location of farm holding } \\
\hline $\begin{array}{l}\text { East } \\
\text { South } \\
\text { West } \\
\text { Mid (Trøndelag) } \\
\text { North }\end{array}$ & $\begin{array}{l}37.8 \\
10.9 \\
23.4 \\
12.5 \\
15.4\end{array}$ & $\begin{array}{l}38.2 \\
11.2 \\
23.3 \\
12.0 \\
15.3\end{array}$ \\
\hline $\begin{array}{l}\text { Majority of family income from the farm } \\
\text { Agricultural education (either family member) } \\
\text { Area of cultivation }\end{array}$ & $\begin{array}{l}36.5 \\
31.7\end{array}$ & $\begin{array}{l}34.4 \\
31.2\end{array}$ \\
\hline $\begin{array}{l}<0.5 \text { ha } \\
0.5-4.9 \text { ha } \\
5.0-9.9 \text { ha } \\
\geq 10 \text { ha }\end{array}$ & $\begin{array}{l}14.6 \\
42.4 \\
25.7 \\
17.3\end{array}$ & $\begin{array}{l}15.7 \\
42.1 \\
24.9 \\
17.3\end{array}$ \\
\hline \multicolumn{3}{|l|}{ Agricultural activity } \\
\hline $\begin{array}{l}\text { Animal farming } \\
\text { Horticulture } \\
\text { Grain farming } \\
\text { Potato cultivation } \\
\text { Forestry }\end{array}$ & $\begin{array}{l}74.4 \\
29.5 \\
34.9 \\
55.5 \\
65.2\end{array}$ & $\begin{array}{l}73.4 \\
30.3 \\
32.5 \\
51.8 \\
68.1\end{array}$ \\
\hline Pesticide purchase ${ }^{b}$ & 36.4 & 37.1 \\
\hline Pesticide spraying equipment ${ }^{6}$ & 28.2 & 28.2 \\
\hline
\end{tabular}

a At the first census of identification of the farm holder.

- Restricted to subjects covered in the 1969 census (men: $N=102584$,

1225691 person-years, females: $N=80990,439312$ person-years).

c Restricted to subjects covered in the 1979 census (men: $N=126467$,

1378095 person-years, females: $N=102143,560983$ person-years). whereas the most of the women $(79 \%)$ were spouses. This distribution explains the difference in the year of the start of follow-up between the men and the women (table 1).

\section{Exposure indicators}

The information in the agricultural censuses formed the basis for establishing the exposure indicators and the other explanatory variables at the time of the census. This information was assigned to all members of the holder's family. Since most were family holdings, even information from the same farm was considered relevant and was included for censuses before the index holder took over. Information from the place of residence was chosen for families who had more than one farm holding at the time of a census ( $5 \%$ of the total). We therefore obtained 1969 census information for $75 \%$ of the holders and spouses. Information from the 1979 and 1989 census was available for $93-95 \%$ of the study population, whereas $3-5 \%$ had information from the horticultural censuses.

The information from the agricultural or horticultural censuses included the municipality of the farm and whether it was the residence of the holder; the farming area and the area used for cultivating potatoes, grain, field vegetables, greenhouse vegetation, berries, and forests; number and species of livestock; number of fruit trees; amount of money spent on pesticides in the preceding year (1969 census); pesticide spraying equipment on the farm (1979 census); source of water (1979 census); use of silage; use of fertilizers (1979 and 1989 censuses); technical equipment on the farm; time spent in agricultural work on the farm and work outside the farm for both holder and spouse; fraction of total family income from the farm; agricultural education of either holder or spouse; and whether a family was holding or not (1979 census). The distribution for selected exposure indicators is given in table 1 . We considered exposure valid only from the census year in which the exposure was recognized (eg, a subject from a farm where grain was cultivated according to the 1979 but not the 1969 census was not considered exposed to grain in the follow-up 1969-1978). However, information given at only one census (eg, pesticide indicators) was used when available.

The exposure indicators were dichotomized in the analyses on the assumption that exposures were as likely to be high for small-scale activities in which work practices were more manual. Orchards and greenhouses were uncommon and were therefore combined, $9 \%$ of all the subjects being exposed.

\section{Cohort categorization}

The information on work input and income on the farm (table 1) indicates that many farms were part-time enter- 
prises with limited agricultural production. We used annual work input on the farm as an indicator of farming activity. Census information on when the holder was first identified was considered the most relevant and was used in the analyses; $52 \%$ of the men and $30 \%$ of the women had a work input of at least $500 \mathrm{~h}$ annually on a farm (table 1). The 500-h limit is the standard criterion applied for a farmer in censuses by Statistics Norway (12). Study subjects who fulfilled the minimum criterion of 500 annual hours of work input on a farm have been called farmers; subjects with less work input on a farm per year have been referred to as nonfarmers.

\section{Statistical methods}

The analyses were performed with the "Epicure" statistical software program (26). Two analytic methods were applied: indirect standardization (observed over expected cases) with an external reference population and Poisson regression modeling with reference populations within the cohort.

The cancer morbidity experience was investigated with indirect standardization, comparing the observed and expected number of cancer cases. The expected number of cases were estimated from the five-year ageand sex-specific rates for the total rural population in Norway for each year from 1969 through 1991. The total rural population was defined as the subjects who lived outside towns and cities at the time of the population census in 1980; it comprised $57 \%$ of the population of Norway (23). Standardized incidence ratios (SIR) were calculated for both total cancer and specific cancer sites if rural reference rates were available. Ninety-five percent confidence intervals ( $95 \% \mathrm{CI}$ ) were computed under the assumption of a Poisson distribution of the observed cancers under the null hypothesis. Confidence limits that were not obtained in the computer analysis were calculated from a table of confidence limit factors for a Poisson-distributed variable (27).

In the Poisson regression analysis, the measure of association was the ratio of incidence rates (RR) between the subjects with the exposure indicator in question and the subjects without the exposure indicator. Rate ratio estimates were adjusted for age and calendar year. Other explanatory variables were included in the models if they altered the estimates of exposure-outcome association by more than $15 \%$ or acted as effect modifiers. Wald-based $95 \%$ confidence intervals were computed, and those that did not include unity were considered statistically significant.

The exposure-outcome associations were investigated for main cancer sites and also for the following specific subsites: nonmelanoma skin cancer of the head and neck (ICD 191.0-191.2); brain cancer (ICD 193.0); acute leukemia; and Hodgkin's disease, divided as to nodular sclerosis and the mixed cellularity type.
Analyses of exposure-outcome associations of particular interest were also performed for the following specific subsets of subjects or person-time: subjects who fulfilled the criterion of a farmer (at least $500 \mathrm{~h}$ of work input on the farm annually); subjects from families where the farm holder lived on the farm at the time of the first census of identification; subjects from farms with the exposure indicator in question for more than one census; and person-time restricted to 15 years' latency or more from the first information on exposure. We considered that the probability was higher for a true exposure for the first two restrictions and that the requirement of an exposure indicator for more than one census was a measure of cumulative exposure, whereas the latency requirement provided more relevant timing of exposure.

\section{Results}

\section{Analyses of standardized incidence ratios}

In the follow-up, 3333 men and 2145 women were identified as cancer cases (table 2). For both the men and women the observed cases and SIR values for the total and site-specific cancers for which the expected number for either gender was higher than 20 are given in table 2 .

The low SIR for total cancer among the men (table 2) was due to significantly low incidences for several sites of the gastrointestinal tract, respiratory system, and urinary system. The men had 100 alcohol-related cases (SIR 63, 95\% CI 52-76) and 740 tobacco-related cases (SIR 75, 95\% CI 70-80). Slight SIR increases were found among the men for the following sites, previously linked to farming: lip, testis, nonmelanoma skin, connective tissue, leukemia, and Hodgkin's disease; leukemia was the only cancer with an excess of borderline significance.

The SIR for total cancer among the women was 104 (95\% CI 99-108). Significantly low SIR values were found for lung cancer and cancer of the uterine cervix (table 2). Increases in the SIR values were found for several cancers, but they were significant only for malignant melanoma and Hodgkin's disease. We observed 28 alcohol-related cases (SIR 97, 95\% CI 65-137) and 150 tobacco-related cases (SIR 86, 95\% CI 73-101).

The results for the subset of farmers are presented in table 3. The low total cancer incidence for the men was due to a low occurrence among the farmers. The SIR values for male farmers was lower for lung cancer in particular, but also for cancers of the stomach, colon, rectum, and bladder, as well as malignant melanoma, nonmelanoma skin cancer, nervous system tumors, and non-Hodgkin's lymphoma. Lip cancer was the only form for which the SIR excess for the whole cohort was restricted to farmers, but the increase was still moderate 
Table 2. Cancers by site in 136463 men (1515 482 person-years) and 109641 women (598 342 person-years) engaged in agriculture according to the Norwegian agricultural censuses, 1969 - 1989. ( $0=$ observed number of cancer cases, SIR = standardized incidence ratio, $95 \% \mathrm{Cl}=95 \%$ confidence interval)

\begin{tabular}{|c|c|c|c|c|c|c|}
\hline \multirow[t]{2}{*}{ Cancer site ${ }^{a}$} & \multicolumn{3}{|c|}{ Men } & \multicolumn{3}{|c|}{ Women } \\
\hline & 0 & SIR & $95 \% \mathrm{Cl}$ & 0 & SIR & $95 \% \mathrm{Cl}$ \\
\hline All sites $(140-209)$ & 3333 & 87 & $84-90$ & 2145 & 104 & $99-108$ \\
\hline Lip (140) & 64 & 120 & $93-152$ & 3 & 123 & $25-318$ \\
\hline Oral cavity $(141,143-148)$ & 59 & 63 & $48-80$ & 17 & 98 & $58-152$ \\
\hline Esophagus (150) & 25 & 60 & $39-86$ & 5 & 101 & $32-218$ \\
\hline Stomach (151) & 176 & 79 & $68-92$ & 40 & 88 & $63-118$ \\
\hline Colon (153) & 258 & 82 & $72--92$ & 157 & 114 & $97-133$ \\
\hline Rectum (154) & 192 & 84 & $73-96$ & 59 & 82 & $62-104$ \\
\hline Liver (155) & 16 & 72 & $42-113$ & 6 & 91 & $33-184$ \\
\hline Pancreas (157) & 80 & 72 & $57-88$ & 36 & 101 & $72-138$ \\
\hline Larynx (161) & 44 & 74 & $54--98$ & - & 0 & $0-148$ \\
\hline Lung (162) & 384 & 70 & $64-78$ & 74 & 72 & $57-90$ \\
\hline Breast (170) & 4 & 65 & $18-151$ & 598 & 105 & $96-113$ \\
\hline Uterine cervix (171) & & $\cdot$ & . & 112 & 81 & $67-97$ \\
\hline Uterine body (172) & . & . & . & 161 & 108 & $92-125$ \\
\hline Ovary (175) & $\cdot$ & . & . & 147 & 92 & $78-107$ \\
\hline Prostate (177) & 277 & 96 & $85-108$ & $\cdot$ & . & . \\
\hline Testicle (178) & 140 & 107 & $90-125$ & $\cdot$ & $\cdot$ & $\cdot$ \\
\hline Kidney (180) & 151 & 85 & $72-99$ & 40 & 103 & $74-139$ \\
\hline Bladder (181) & 232 & 86 & $75-97$ & 40 & 119 & $86-159$ \\
\hline Melanoma (190) & 281 & 98 & $87-110$ & 181 & 116 & $100-133$ \\
\hline Skin (191) & 94 & 105 & $85-128$ & 34 & 118 & $83-163$ \\
\hline Eye (192) & 19 & 96 & $59-146$ & 8 & 164 & $72-305$ \\
\hline Nervous system (193) & 197 & 98 & $85-112$ & 104 & 119 & $98-144$ \\
\hline Thyroid (194) & 48 & 116 & $86-152$ & 60 & 118 & $91-151$ \\
\hline Connective tissue (197) & 30 & 117 & $80-164$ & 12 & 145 & $75-244$ \\
\hline Multiple myeloma (203) & 52 & 93 & $70-120$ & 21 & 115 & $72-171$ \\
\hline Leukemia (204) & 100 & 122 & $100-148$ & 20 & 87 & $54-130$ \\
\hline Hodgkin's disease (201) & 57 & 120 & $91-154$ & 15 & 193 & $111-308$ \\
\hline Non-Hodgkin's lymphoma $(200,202)$ & 154 & 95 & $80-110$ & 73 & 117 & $92-145$ \\
\hline Other or unspecified (199) & 92 & 74 & $60-90$ & 50 & 108 & $81-141$ \\
\hline Remaining sites & 107 & 91 & $75-110$ & 72 & 147 & $115-185$ \\
\hline
\end{tabular}

a Code of the International Classification of Diseases, seventh revision, in parentheses.

Table 3. Selected cancers by site among male and female farmersa engaged in agriculture according to Norwegian agricultural censuses, 1969-1989. ( 0 = observed number of cancer cases, $S I R=$ standardized incidence ratio, $95 \% \mathrm{Cl}=95 \%$ confidence interval)

\begin{tabular}{|c|c|c|c|c|c|c|}
\hline \multirow[t]{2}{*}{ Cancer site ${ }^{b}$} & \multicolumn{3}{|c|}{ Men } & \multicolumn{3}{|c|}{ Women } \\
\hline & 0 & SIR & $95 \% \mathrm{Cl}$ & 0 & SIR & $95 \% \mathrm{Cl}$ \\
\hline All sites $(140-209)$ & 1527 & 77 & $73-81$ & 590 & 92 & $85-99$ \\
\hline Lip (140) & 39 & 137 & $98-184$ & 2 & 278 & $28-858$ \\
\hline Stomach (151) & 82 & 70 & $56-86$ & 8 & 55 & $24-102$ \\
\hline Colon (153) & 114 & 70 & $58-84$ & 45 & 101 & $75-134$ \\
\hline Rectum (154) & 78 & 67 & $53-83$ & 18 & 78 & $47-120$ \\
\hline Lung (162) & 143 & 51 & $43-60$ & 14 & 43 & $24-69$ \\
\hline Breast $(170)$ & & & & 148 & 84 & $72-99$ \\
\hline Uterine cervix (171) & & . & . & 28 & 69 & $47-98$ \\
\hline Uterine body (172) & & & & 57 & 118 & $90-151$ \\
\hline Prostate (177) & 129 & 90 & $75-107$ & . & . & . \\
\hline Testicle (178) & 80 & 109 & $87-134$ & . & . & . \\
\hline Bladder (181) & 101 & 73 & $60-88$ & 14 & 128 & $72-207$ \\
\hline Melanoma (190) & 123 & 83 & $69-98$ & 52 & 111 & $84-144$ \\
\hline Skin (191) & 40 & 89 & $64-119$ & 5 & 55 & $18-119$ \\
\hline Eye (192) & 11 & 106 & $53-182$ & 3 & 199 & $41-581$ \\
\hline Nervous system (193) & 95 & 88 & $71-107$ & 27 & 101 & $68-144$ \\
\hline Thyroid (194) & 27 & 124 & $83-177$ & 17 & 116 & $69-181$ \\
\hline Connective tissue (197) & 16 & 113 & $66-177$ & 3 & 122 & $25-315$ \\
\hline Multiple myeloma (203) & 27 & 92 & $61-131$ & 5 & 83 & $27-179$ \\
\hline Leukemia (204) & 56 & 127 & $96-163$ & 11 & 156 & $78-268$ \\
\hline Hodgkin's disease (201) & 33 & 125 & $87-172$ & 4 & 177 & $48-410$ \\
\hline Non-Hodgkin's lymphoma $(200,202)$ & 69 & 82 & $64-103$ & 20 & 104 & $64-156$ \\
\hline Alcohol related cancers $(141,143-148,150,155)$ & 45 & 56 & $41-74$ & 9 & 97 & $44-174$ \\
\hline Tobacco-related cancers $(157,161,162,181)$ & 298 & 59 & $53-66$ & 42 & 75 & $54-99$ \\
\hline
\end{tabular}

a Subjects working $\geq 500$ annual hours on a farm (men: $N=66080,836597$ person-years; women: $N=30218,174028$ person-years).

b Code of the International Classification of Diseases, seventh revision, in parentheses.

and of borderline significance. The subset of female farmers also had a lower total cancer SIR than the whole cohort. In particular, the lung cancer SIR for the farmers was low, whereas the SIR values for other tobacco- and 
alcohol-related cancers were close to those of the total rural population. Compared with a lung cancer SIR as low as 43 for female farmers, the bladder cancer SIR of 128 was unexpectedly high. The farmers also had distinctly lower SIR values for breast cancer, cervical cancer, stomach cancer, and nonmelanoma skin cancer.

Among the nonfarmers the SIR for total cancer was close to unity (1806 cases, SIR 98, 95\% CI 94-103) for the men and slightly increased (1555 cases, SIR 110, 95\% CI 104-115) for the women. The latter was primarily due to the increased breast cancer incidence (SIR $114,95 \%$ CI 104-125). Nonfarmers of both genders had a lung cancer SIR close to unity, and increases in melanoma (men: SIR 116, 95\% CI 99-135; women: SIR 118, 95\% CI 98-139) and nonmelanoma skin cancer (men: SIR 122, 95\% CI 92-157; women: SIR 147, 95\% CI 100-208).

Lung cancer among the men and breast cancer among the women were the most common forms of carcinoma, and clear differences were found between the farmers and nonfarmers. Figure 1 shows the age-specific lung cancer rates for the male farmers and nonfarmers. The farmers had lower rates than the nonfarmers at all ages; the relative difference between the two groups was larger above 50 years of age. Figure 2 shows that even the breast cancer rates were lower for the farmers than for the nonfarmers in all the age groups; the relative difference was largest for the premenopausal age group. The fact that the female farmers had more children than the female nonfarmers might explain the difference. We included age, parity, and farmer-nonfarmer status in a Poisson regression model. The results indicated a somewhat

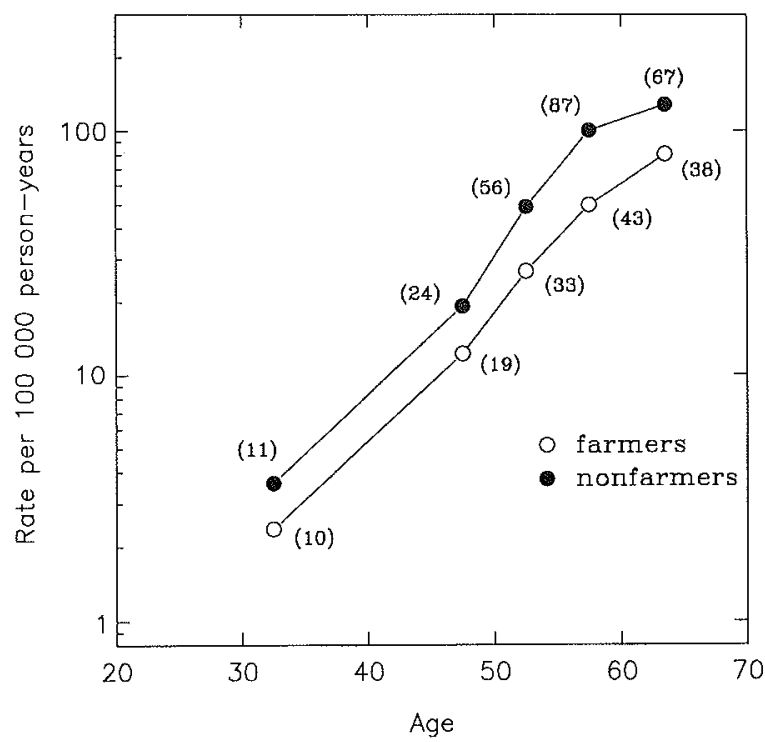

Figure 1. Lung cancer rates by age for the male farmers and nonfarmers engaged in agriculture according to Norwegian agricultural censuses in 1969-1989. (farmers: subjects working $\geq 500$ annual hours on a farm holding, nonfarmers: subjects working $<500$ annual hours on a farm holding, - number of cases in parentheses) different age profile for the farmers than for the nonfarmers, in agreement with figure 2 . This modeling also indicated that the beneficial effect of child birth was larger among the farmers than the nonfarmers. However, parity only explained a minor portion of the difference between the farmers and nonfarmers (data not shown)

\section{Exposure-cancer associations in the Poisson regression modeling}

The results of the Poisson regression analysis for the exposure indicators given in the a priori hypotheses are shown in table 4 . Dairy cattle was associated with male acute leukemia (total 54 cases, 33 exposed cases, RR $1.76,95 \%$ CI 1.02-3.05). The estimate for the subjects living on a farm was slightly higher, whereas estimates for farmers and for dairy cattle in more than one census was slightly lower, and considerably lower when the analysis was restricted to a latency time of over 15 years (table 5).

Positive, but unstable estimates were also found for orchards and greenhouses in association with Hodgkin's disease among the men, as well as for orchards and greenhouses and soft-tissue sarcoma among the women (table 4). However, the two cancers were not positively associated with the pesticide indicators, and associations for subsets considered to be more precise were markedly weaker (data not shown). Hodgkin's disease, in particular nodular sclerosis, was even more strongly associated with field vegetables. The nodular sclerosis risk ratio for the men in association with field vegetables was 2.40 (95\% CI 0.95-6.09), based on eight exposed out of a total of 18 cases. The same association was positive even

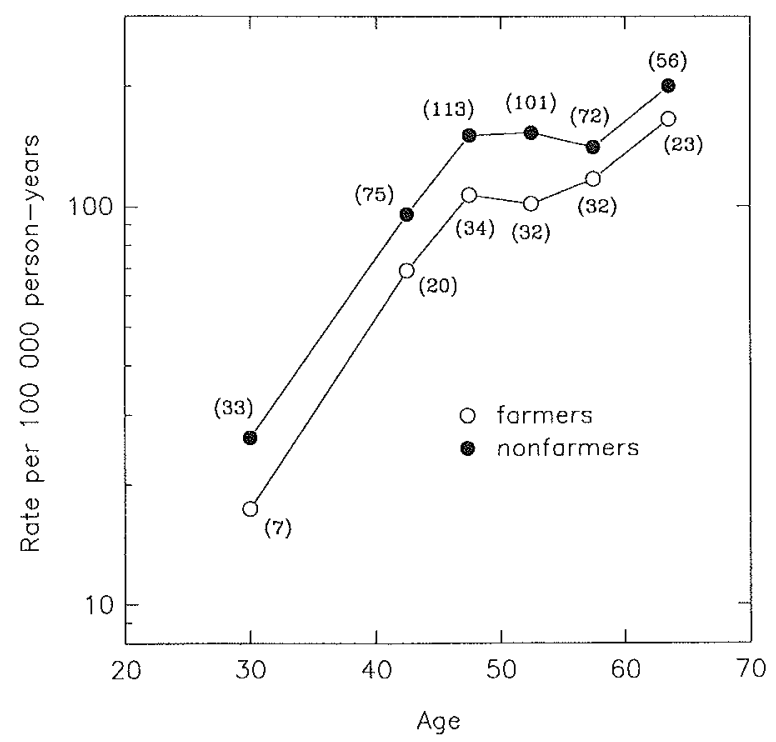

Figure 2. Breast cancer rates by age for the female farmers and nonfarmers engaged in agriculture according to Norwegian agricultural censuses in 1969-1989. (farmers: subjects working $\geq 500$ annual hours on a farm holding, nonfarmers: subjects working $<500$ annual hours on a farm holding, - number of cases in parentheses) 
for the women, but there were only four exposed cases (total 10 cases) and wide confidence limits (RR 1.93, 95\% CI 0.54-6.85).

For both the men and the women, $50 \%$ nonsignificant risk increases were found for multiple myeloma in association with pesticide purchase (table 4). The pesti- cide indicator was related to orchards and greenhouses among the women, but not among the men. Multiple myeloma was more strongly associated with potato cultivation for both the men and the women; this association was strengthened for farms for which pesticide indicators were also reported (tables 5 and 6). The association

Table 4. A priori suspected associations between cancer and exposure indicators for the men ( $N=136463,1515482$ person-years) and women ( $N=109641,598342$ person-years) engaged in agriculture according to the Norwegian agricultural censuses, $1969-1989$. $(95 \% \mathrm{Cl}=95 \%$ confidence interval)

\begin{tabular}{|c|c|c|c|c|c|c|c|}
\hline \multirow[t]{2}{*}{ Cancer diagnosis } & \multirow[t]{2}{*}{ Exposure indicator } & \multicolumn{3}{|c|}{ Men } & \multicolumn{3}{|c|}{ Women } \\
\hline & & $\begin{array}{l}\text { Exposed } \\
\text { cases }\end{array}$ & $\begin{array}{l}\text { Rate } \\
\text { ratio }\end{array}$ & $95 \% \mathrm{Cl}$ & $\begin{array}{l}\text { Exposed } \\
\text { cases }\end{array}$ & $\begin{array}{l}\text { Rate } \\
\text { ratio }\end{array}$ & $95 \% \mathrm{Cl}$ \\
\hline Acute leukemia & $\begin{array}{l}\text { Dairy cattle } \\
\text { Chicken } \\
\text { Orchards and greenhouses } \\
\text { Pesticide purchase }^{b}\end{array}$ & $\begin{array}{r}33 \\
13 \\
7 \\
17\end{array}$ & $\begin{array}{l}1.76 \\
0.89 \\
1.51 \\
0.93\end{array}$ & $\begin{array}{l}1.02-3.05 \\
0.48-1.67 \\
0.68-3.35 \\
0.51-1.69\end{array}$ & $\begin{array}{l}7 \\
1 \\
2 \\
3\end{array}$ & $\begin{array}{l}1.22 \\
0.21 \\
1.69 \\
0.56\end{array}$ & $\begin{array}{l}0.44-3.37 \\
0.03-1.61 \\
0.38-7.52 \\
0.15-2.06\end{array}$ \\
\hline Hodgkin's disease & $\begin{array}{l}\text { Cattle } \\
\text { Orchards and greenhouses } \\
\text { Pesticide purchase }\end{array}$ & $\begin{array}{r}25 \\
9 \\
17\end{array}$ & $\begin{array}{l}0.98 \\
1.85 \\
0.93\end{array}$ & $\begin{array}{l}0.58-1.66 \\
0.91-3.77 \\
0.51-1.69\end{array}$ & $\begin{array}{l}3 \\
1 \\
4\end{array}$ & $\begin{array}{l}0.43 \\
0.76 \\
1.43\end{array}$ & $\begin{array}{l}0.12-1.53 \\
0.10-5.76 \\
0.38-5.35\end{array}$ \\
\hline Non-Hodgkin's lymphoma & $\begin{array}{l}\text { Cattle } \\
\text { Forestry } \\
\text { Grain farming } \\
\text { Orchards and greenhouses } \\
\text { Pesticide purchaseb }\end{array}$ & $\begin{array}{r}45 \\
103 \\
52 \\
9 \\
43\end{array}$ & $\begin{array}{l}0.61 \\
0.87 \\
0.99 \\
0.64 \\
0.98\end{array}$ & $\begin{array}{l}0.43-0.86 \\
0.62-1.22 \\
0.71-1.38 \\
0.33-1.25 \\
0.67-1.43\end{array}$ & $\begin{array}{r}24 \\
52 \\
23 \\
4 \\
22\end{array}$ & $\begin{array}{l}0.91 \\
1.12 \\
1.01 \\
0.63 \\
1.12\end{array}$ & $\begin{array}{l}0.55-1.48 \\
0.67-1.86 \\
0.62-1.66 \\
0.23-1.73 \\
0.66-1.91\end{array}$ \\
\hline Multiple myeloma & $\begin{array}{l}\text { Orchards and greenhouses } \\
\text { Pesticide purchase }\end{array}$ & $\begin{array}{r}2 \\
20\end{array}$ & $\begin{array}{l}0.42 \\
1.56\end{array}$ & $\begin{array}{l}0.10-1.71 \\
0.85-2.86\end{array}$ & $\begin{array}{l}4 \\
8\end{array}$ & $\begin{array}{l}2.61 \\
1.49\end{array}$ & $\begin{array}{l}0.88-7.76 \\
0.59-3.77\end{array}$ \\
\hline Soft tissue sarcoma & $\begin{array}{l}\text { Cattle } \\
\text { Forestry } \\
\text { Grain farming } \\
\text { Orchards and greenhouses } \\
\text { Pesticide purchase }^{\text {b }}\end{array}$ & $\begin{array}{r}10 \\
18 \\
10 \\
1 \\
8\end{array}$ & $\begin{array}{l}0.60 \\
0.66 \\
0.88 \\
0.34 \\
0.83\end{array}$ & $\begin{array}{l}0.28-1.30 \\
0.32-1.36 \\
0.41-1.88 \\
0.05-2.52 \\
0.35-1.96\end{array}$ & $\begin{array}{r}6 \\
5 \\
\\
3 \\
2\end{array}$ & $\begin{array}{l}2.14 \\
0.34 \\
0 \\
3.90 \\
0.69\end{array}$ & $\begin{array}{l}0.68-6.71 \\
0.11-1.08 \\
0.00-0.95 \\
1.05-14.47 \\
0.14-3.42\end{array}$ \\
\hline Brain tumor & $\begin{array}{l}\text { Pig farming } \\
\text { Orchards and greenhouses } \\
\text { Pesticide purchaseb }\end{array}$ & $\begin{array}{l}50 \\
14 \\
49\end{array}$ & $\begin{array}{l}1.05 \\
1.09 \\
1.26\end{array}$ & $\begin{array}{l}0.75-1.48 \\
0.63-1.89 \\
0.87-1.82\end{array}$ & $\begin{array}{r}11 \\
3 \\
12\end{array}$ & $\begin{array}{l}0.63 \\
0.72 \\
1.17\end{array}$ & $\begin{array}{l}0.32-1.27 \\
0.22-2.32 \\
0.56-2.44\end{array}$ \\
\hline
\end{tabular}

a Adjusted for age and period.

b Restricted to subjects covered in the 1969 census (men: $N=102584,1225691$ person-years; women: $N=80990,439312$ person-years).

Table 5. Positive associations between cancer and the exposure indicators for the men born in 1925-1971 ( $N=136463,1515482$ person-years), engaged in agriculture according to the Norwegian agricultural censuses, $1969-1989$. ( $\mathrm{RR}=$ rate ratio, $95 \% \mathrm{Cl}=95 \%$ confidence interval)

\begin{tabular}{|c|c|c|c|c|c|c|c|c|c|}
\hline \multirow[t]{2}{*}{ Site or morphology } & \multirow[t]{2}{*}{ Exposure indicator } & \multicolumn{4}{|c|}{ Total study population } & \multicolumn{4}{|c|}{$\mathrm{RR}^{\mathrm{a}}$ estimates for population subsets } \\
\hline & & $\begin{array}{l}\text { Exposed } \\
\text { cases }\end{array}$ & $\begin{array}{l}\text { Person- } \\
\text { years }\end{array}$ & $\mathrm{RR}^{\mathrm{a}}$ & $95 \% \mathrm{Cl}$ & $\begin{array}{l}\text { Lives } \\
\text { on farm }\end{array}$ & Farmers & $\begin{array}{l}\text { Exposed } \\
\text { at the } \\
\text { time of } \\
\text { more than } \\
\text { one census }\end{array}$ & $\begin{array}{l}\text { Latency } \\
15 \text { years } \\
\mathrm{s}\end{array}$ \\
\hline Acute leukemia & Dairy cattle & 33 & 723238 & 1.76 & $1.02-3.05$ & 1.85 & 1.69 & 1.65 & 1.32 \\
\hline Multiple myeloma & $\begin{array}{l}\text { Potato cultivation } \\
\text { Potato plus pesticide purchase }\end{array}$ & $\begin{array}{l}35 \\
19\end{array}$ & $\begin{array}{l}841347 \\
360617\end{array}$ & $\begin{array}{l}1.65 \\
2.46\end{array}$ & $\begin{array}{l}0.92-2.95 \\
1.03-5.85\end{array}$ & $\begin{array}{l}1.83 \\
2.86\end{array}$ & $\begin{array}{l}2.90 \\
6.34\end{array}$ & $\begin{array}{l}1.67 \\
\cdot .\end{array}$ & $\begin{array}{l}2.69 \\
2.96\end{array}$ \\
\hline Malignant melanoma & Pesticide purchase $e^{b, c}$ & 94 & 468110 & 1.37 & $1.03-1.82$ & 1.39 & 1.28 & .. & 1.26 \\
\hline $\begin{array}{l}\text { Nonmelanoma skin } \\
\text { (head or neck) }\end{array}$ & Grain farming & 25 & 529548 & 1.93 & $0.97-3.81$ & 2.31 & 2.70 & 2.03 & 1.91 \\
\hline Lip & Horses ${ }^{d}$ & 22 & 311884 & 1.90 & $1.13-3.20$ & 1.78 & 1.46 & 3.03 & 2.56 \\
\hline Prostate & Orchards and greenhouses & 33 & 137064 & 1.45 & $1.01-2.09$ & 1.47 & 1.09 & 1.45 & 1.33 \\
\hline Testicular & Orchards and greenhouses & 20 & 137064 & 1.63 & $1.01-2.62$ & 1.38 & 1.48 & 1.67 & 2.43 \\
\hline Brain tumor & Grain farming ${ }^{\circledR}$ & 53 & 529548 & 1.51 & $0.98-2.30$ & 1.56 & 0.99 & 1.54 & 1.34 \\
\hline
\end{tabular}

a Adjusted for age and period unless otherwise stated

b Restricted to men covered in the 1969 census ( $N=102584,1225691$ person-years).

- Adjusted for age, period, and region.

Adjusted for age, period, region, and agricultural education.

e Adjusted for age, period, fraction of family income from farm holding, and agricultural education. 
Table 6. Positive associations between cancer and the exposure indicators for the women born in 1925-1971 ( $N=109641,598342$ person-years) and engaged in agriculture according to Norwegian agricultural censuses in $1969-1989$. ( $\mathrm{RR}=$ rate ratio, $95 \% \mathrm{Cl}=95 \%$ confidence interval)

\begin{tabular}{|c|c|c|c|c|c|c|c|c|c|}
\hline \multirow[t]{2}{*}{ Site or morphology } & \multirow[t]{2}{*}{ Exposure indicator } & \multicolumn{4}{|c|}{ Total study population } & \multicolumn{4}{|c|}{$R^{\mathrm{a}}$ estimates for population subsets } \\
\hline & & $\begin{array}{l}\text { Exposed } \\
\text { cases }\end{array}$ & $\begin{array}{c}\text { Person- } \\
\text { years }\end{array}$ & $R^{a}$ & $95 \% \mathrm{Cl}$ & $\begin{array}{l}\text { Lives } \\
\text { on farm }\end{array}$ & Farmers & $\begin{array}{l}\text { Exposed } \\
\text { at the } \\
\text { time of } \\
\text { more than } \\
\text { one census }\end{array}$ & $\begin{array}{l}\text { Latency } \\
15 \text { years } \\
\text { s }\end{array}$ \\
\hline Multiple myeloma & $\begin{array}{l}\text { Potato cultivation } \\
\text { Potato plus pesticide purchase }\end{array}$ & $\begin{array}{r}13 \\
6\end{array}$ & $\begin{array}{l}310414 \\
124404\end{array}$ & $\begin{array}{l}1.64 \\
2.03\end{array}$ & $\begin{array}{l}0.68-3.96 \\
0.51-8.14\end{array}$ & $\begin{array}{l}1.78 \\
1.82\end{array}$ & $\infty$ & $\begin{array}{c}1.94 \\
. .\end{array}$ & $\begin{array}{l}1.88 \\
1.87\end{array}$ \\
\hline Malignant melanoma & Pesticide purchaseb,c & 59 & 159090 & 1.37 & $0.96-1.95$ & 1.46 & 1.61 &.. & 1.27 \\
\hline $\begin{array}{l}\text { Nonmelanoma skin } \\
\text { (head or neck) }\end{array}$ & Field vegetables & 6 & 150196 & 2.54 & $0.85-7.55$ & 3.90 & 3.99 & 5.94 & 3.10 \\
\hline Colon & $\begin{array}{l}\text { Field vegetables } \\
\text { Field vegetables plus } \\
\text { pesticide purchase }\end{array}$ & $\begin{array}{l}54 \\
30\end{array}$ & $\begin{array}{r}150196 \\
66992\end{array}$ & $\begin{array}{l}1.60 \\
1.89\end{array}$ & $\begin{array}{l}1.15-2.22 \\
1.24-2.87\end{array}$ & $\begin{array}{l}1.78 \\
2.00\end{array}$ & $\begin{array}{l}1.52 \\
1.96\end{array}$ & $\begin{array}{l}0.94 \\
1.40\end{array}$ & $\begin{array}{l}1.63 \\
2.89\end{array}$ \\
\hline Uterine body & $\begin{array}{l}\text { Pig farming } \\
\text { Grain farming }\end{array}$ & $\begin{array}{l}66 \\
71\end{array}$ & $\begin{array}{l}181180 \\
193194\end{array}$ & $\begin{array}{l}1.74 \\
1.83\end{array}$ & $\begin{array}{l}1.27-2.38 \\
1.34-2.50\end{array}$ & $\begin{array}{l}1.79 \\
1.93\end{array}$ & $\begin{array}{l}1.68 \\
2.00\end{array}$ & $\begin{array}{l}1.72 \\
1.86\end{array}$ & $\begin{array}{l}1.84 \\
1.95\end{array}$ \\
\hline Ovary & Chicken farming ${ }^{d}$ & 47 & 156436 & 1.52 & $1.07-2.17$ & 1.59 & 2.04 & 2.45 & 1.71 \\
\hline Urinary bladder & Orchards and greenhousese & 6 & 52917 & 2.35 & $0.97-5.70$ & 1.78 & 2.90 & 0.74 & 2.29 \\
\hline Thyroid & Orchards and greenhouses ${ }^{d}$ & 11 & 52917 & 2.00 & $1.02-3.91$ & 1.85 & 1.32 & 3.38 & 2.03 \\
\hline
\end{tabular}

a Adjusted for age and period unless otherwise stated.

- Restricted to women covered in the 1969 census ( $\mathbb{N}=80990,439312$ person-years).

c Adjusted for age, period, and region.

$\checkmark$ Adjusted for age, period, and parity.

e Adjusted for age, period, and agricultural education.

was of borderline significance for the men and nonsignificant for the women, but the associations for the subsets anticipated to have more precise estimates were mostly stronger than for the total cohort.

Malignant melanoma showed positive associations with several of the types of farming that are common in the southern part of Norway. However, melanoma rates in Norway have a strong north-south gradient, and most of the associations were close to unity after adjustment for region. A moderate association of borderline significance remained for pesticide purchase for both the men and the women even after adjustment for region (tables 5 and 6).

Nonmelanoma skin cancer of the head and neck (49 cases among the men and 13 cases among the women) was associated with types of farming compatible with sun exposure, that is, grain farming for the men (table 5) and cultivation of field vegetables for the women (table 6). Except for the restriction of 15 years' latency for the men, both associations were strengthened for the subsets of more precise estimates. Eye cancer cases were too few for meaningful analysis.

Lip cancer was associated with animal husbandry and was strongest for horses (table 5). Associations were strong and significant even for cattle, more moderate for sheep, but close to unity for pigs and poultry (data not shown). Lip cancer was far more common among the men, and only three cases were identified among the women, all of which were associated with exposure to animal farms.
Both cancer of the prostate and cancer of the testis were associated with orchards and greenhouses (table 5), but they showed moderate negative associations with the pesticide indicators, and were only moderately associated with horticulture and pesticides combined (data not shown).

The men had a total of 145 brain tumors, and a positive association of borderline significance was present for grain farming (table 5). The association was markedly lower for the farmers and for a latency time of over 15 years.

Several positive associations were found between cancer among the women and the exposure indicators (table 6). Colon cancer was associated with field vegetables on a farm, and the rate ratio estimate was nearly doubled for field vegetables combined with pesticides. Cancer of the uterine body was positively associated with several exposure indicators. After adjustment, independent and highly significant associations remained for pig farming and grain farming. Ovarian cancer showed a significant $50 \%$ increase in association with poultry farming, based on 47 exposed cases. The point estimates were higher for the subjects living on a farm, for farmers, for those exposed at the time of more than one census, and when follow-up was restricted to a latency time of 15 years. Both bladder cancer and thyroid cancer were associated with orchards and greenhouses, although the associations were based on few exposed cases. Both of the associations were mostly restricted to exposed cases in the western part of Norway, where 
orchards are common, and they were both of borderline significance.

\section{Discussion}

\section{Results}

In this cohort study the total cancer incidence among the men in the agricultural sector was considerably lower than for the total rural population. The female study subjects had a total cancer incidence close to the total rural population. Our results demonstrate that the cancer pattern in this cohort is heterogeneous for both the men and the women. The total cancer incidence was markedly lower for the subjects who were defined as farmers according to the standard occupational criterion, compared with that of the nonfarmers. Male farmers had a total cancer experience in agreement with results for farmers in other studies $(4,5,9)$, whereas the female farmers had a higher total cancer SIR than Danish farmers (9).

The difference between the observed and expected cases can be expressed as the prevented fraction (28), defined as the difference between the reference rate and the index rate, divided by the reference rate. When the nonfarmers were considered the reference group and the farmers the index population, the prevented fraction of farming, as adjusted for age and period, was 0.21 for the men and 0.17 for the women. When the national rural population was considered to be the reference, the adjusted prevented fraction was 0.23 for the men and 0.08 for the women.

The differences in tobacco- and alcohol-related cancers and gastrointestinal cancers account for most of the total cancer difference between the male farmers and nonfarmers. For the women, breast cancer had the largest impact on the difference between the farmers and nonfarmers, but also cancer of the lung and uterine cervix was important. The results indicate that the farmers of both genders had favorable habits with respect to several life-style factors, and they therefore agree with results from other countries $(4,5,9)$.

Surveys of smoking habits have been performed annually in Norway since 1973 . For the adult female population, the percentage of daily smokers during the $1970 \mathrm{~s}$ in agriculture, fishing and forestry was 12 , compared with $37 \%$ of the total female adult population. For the men the corresponding percentages were 43 and 53 . Smoking prevalences were two to three percentage points lower for the rural population than for the total population (Hilde Rudlaug, National Council on Tobacco and Health, personal communication, 1994). When Axelson's method (29) is applied, these figures can be used to assess the impact of smoking on lung cancer in our farming population. Let the relative risk of daily smoking for lung cancer be 20 and the percentages of daily smokers among the female farmers, the female rural reference group, the male farmers, and the male rural reference group be $10,35,40$, and 50, respectively. Smoking alone would then yield an SIR estimate of 38 for the women and 82 for the men. The actual SIR values were 43 for the female farmers and 51 for the male farmers. It is therefore possible that smoking male farmers smoked less than other smokers or they were exposed to unaccounted factors that are protective. However, interpretations without individual information on smoking habits should be made with caution - the smoking epidemic in Norway has shown complex trends influenced by social changes and the level of awareness of the health hazards involved (30). There are indications that farmers follow the national trends, but with a delay in time and at a lower prevalence level (31).

We anticipated a correlation between the level of farming activity and cancer incidence for farm-related sites. Apart from lip cancer among the men and Hodgkin's disease among the women, such a correlation did not appear; for most of the "farm-related" cancer sites, there were no specific patterns and only small differences between the farmers and nonfarmers. The nonfarmers had in fact higher SIR values than the farmers for stomach cancer, melanoma, and nonmelanoma skin cancer, and other sites. It is reasonable that this pattern is real for stomach cancer. The population under study was rather young, and the follow-up was for recent years. The socioeconomic status of the families in modern Norwegian farming is relatively high (32). The social structure of the farmers of the cohort may differ from that of older agricultural populations and some other countries where increased risk of stomach cancer has been shown (4).

The high socioeconomic status may also explain the fact that the SIR excess of lip cancer was lower than in most other studies (4). Further follow-up is needed to determine if this is a true birth cohort effect; lip cancer occurs mainly among old men, and some of the gradients seen among older men are less pronounced at younger ages (eg, urban-rural difference) (23).

Several significant positive associations were found between the exposure indicators and specific cancers. However, they should be interpreted with caution since many associations were investigated.

The most interesting confirmation of an a priori hypothesis was the relationship between acute leukemia among the men and dairy cattle. In many studies, mostly in the United States and New Zealand (3), the risk of leukemia for agricultural and slaughterhouse workers has been linked to animals. The mechanism is unknown, but a viral etiology or causation by animal insecticides has been suspected. Different subtypes of leukemia have been studied $(2,3)$. Our population was young, and most 
of the leukemia cases were acute. Changes in the leukemia classification of the cancer register during the study period made it difficult to interpret the results of moredetailed subtyping.

Our results suggest an association between pesticides in potato cultivation and multiple myeloma. Multiple myeloma has been related to farming in several studies with male subjects $(4,33)$, whereas the associations between multiple myeloma and farming or farm exposures among women are less consistent (34-39). Pesticide exposure has been suspected as a risk factor in several studies (40-43), but potato cultivation has, to our knowledge, not been addressed, although fungicides and other pesticides commonly used in potato farming have received attention (14).

Lip cancer is recognized as a farm-related cancer, and it is also related to other outdoor occupations (4, 44, 45). Unexpectedly, we found a relationship between lip cancer and animal contact. It is interesting that lip cancer has been associated with dairy farming in New Zealand (46) and that a viral origin has been suggested (45). Like many other farm-related cancers (4), lip cancer can be considered immune-related, and the risk is strongly increased among immunosuppressed patients $(47,48)$.

The work pattern in agricultural work in Norway (49) makes sun exposure a plausible explanation for the associations found for nonmelanoma skin cancer. The work in grain farming is to a large degree carried out in the fields during the summer, usually by the male farmer on a tractor; female farmers often take part in work in the vegetable fields during the summer season. A stronger association for cancer located in the area of the head and neck is in agreement with the findings of other studies $(5,50)$.

The evidence for causality for the other revealed associations was not so strong. An association between the pesticide exposure indicator and melanoma was found for both the men and the women, but it was moderate. A connection between pesticides and melanoma has been suggested earlier (51), but the evidence is scarce. Pesticides are mostly used in southern Norway, and confounding from sun exposure may partly remain even after adjustment for region.

The link of pig farming and grain farming to cancer of the uterine body has not been reported earlier. Contrary to other gynecological cancers, rural and urban incidences are similar for uterine cancer (11), even if parity in rural populations is often higher. The high-risk groups in our cohort had more children than the average, and the finding was unexpected.

The combination of a low lung cancer incidence and a rather high bladder cancer incidence among the female farmers was unexpected. This discrepancy was not found among the men and may indicate that female farmers are exposed to occupational bladder carcino- gens. The association with orchards and greenhouses is in agreement with the risk excess of the same magnitude found among Swedish professional gardeners (52). Excess bladder cancer has also been reported for male orchard farmers (37).

Orchard and greenhouse farming was also associated with thyroid cancer among the women. Thyroid cancer has a strong geographic gradient in the country, with high rates in the northern part of Norway and in coastal regions (53). During 1982-1991 the thyroid cancer incidence was higher for women in the part of western Norway where orchards are common than in surrounding parts (53).

The association between grain farming and brain tumors among the men is in agreement with the results of a previous report (54), but we found no risk increase in combination with pesticide exposure indicators, as earlier reports indicate $(55,56)$.

The low SIR values for colorectal cancer among the male farmers is in agreement with the finding presented in other reports $(4,57)$. The interpretation is not straightforward. Dietary intake of animal fat has been high and the intake of fruit and vegetables low among farmers in national surveys (58), but high physical activity was likely in this group and may be protective. The women, in particular nonfarmers, had a moderate increase in colon cancer. The associations between field vegetables in combination with pesticides and colon cancer among the women was unexpected since a diet high in vegetables could be anticipated among farmers who grow them.

Fortuity is a likely explanation for the association between horticulture and both cancer of the prostate and testis. The associations were of borderline significance, and both were considerably weaker when combined with indicators of pesticide exposure, which has been related to prostate cancer $(4,59)$ and testicular cancer $(60)$ in earlier reports.

\section{Validity}

Norwegian agriculture is dominated by family farms, and the cohort under study comprised the majority engaged in agricultural work and born after 1924. The personal identification number made complete identification and linkage possible, except for dead spouses. Negative bias due to the selective loss of decedents with cancer could have been a problem (61), but it was avoided because the follow-up of spouses started after the identification in the population register (1986).

Several factors introduced nondifferential misclassification in both the SIR analysis and the Poisson regression modeling. The most serious problem was the crude, inaccurate exposure indicators available. We had information on the activity on the farms but not on the actual exposures of interest. Pesticide use is an example. We 
had only information on money spent on pesticides or spraying equipment, and we had to assume that these indicators, in combination with specific types of farming, reflected exposures to specific groups of pesticides. Although the approval, uses, and application of pesticides have been firmly regulated in Norway (62), our assumptions can be questioned. Our exposure data were also based on periodic censuses; they were therefore of a cross-sectional nature. We made assumptions concerning activity on a farm between or before the census years, and these assumptions are likely to introduce misclassification. The subset analyses for subjects with exposure at the time of more than one census and followup with a latency time of 15 years are probably also of limited value. The majority of the subjects came from family farms and were likely to have been exposed to factors on the farm long before the 1969 census. The limitations of the quality of the information on exposure and its timing were not, however, related differentially to the outcomes under study. The result of such nondifferential misclassification for dichotomous categories would be a bias towards unity for any true association. We should therefore regard the results for the unconfirmed hypotheses as nonpositive rather than as negative.

The misclassification problems in the SIR analysis should have had less potential influence on the point estimates. Nearly $90 \%$ of the farms were located in rural municipalities, and a large proportion of the study population therefore contributed to the person-time experience of the reference (total rural) population. Even if the study cohort size was about $15 \%$ of that of the total rural population, the contribution to both the numerator and the denominator biases SIR values only a few percent towards unity for estimates not too far from unity. With a "worst-case" scenario, considering all study subjects as part of the rural population, all the study subjects could be subtracted from the reference population. The SIR for lip cancer among the men would then have increased from 120 to about 124 , whereas the lung cancer SIR for the men would have decreased from 70 to 66 . The loose inclusion criteria in the agricultural censuses and the large proportion of farms with a low agricultural work input introduces problems of the same nature: a "dilution" by introducing marginal farmers into the cohort and a bias of SIR estimates towards unity. We solved this problem by performing separate analyses for farmers defined according to the standard occupational code.

Finally, we lacked individual information on several explanatory factors for cancer, the most important being smoking habits and other life-style factors. This deficit puts restraints on the interpretations of our study. Historical survey data on the group level for such factors offer only incomplete solutions and answers.

\section{Acknowledgments}

The supervision and advice offered by Professor Tor Bjerkedal and Professor Tor Norseth during all stages of the study are acknowledged. We thank Steinar Hansen and Aage Johansen for the file linking and preparation in the Cancer Registry, Oddvar Sandvin for designing the reference rate files, and Hilde Rudlaud at the National Council on Tobacco and Health for providing survey smoking data.

This work was supported by the Research Council of Norway (grant no 103542/110).

\section{References}

1. Blair A, Malker H, Cantor KP, Burmeister L, Wiklund K. Cancer among farmers: a review. Scand J Work Environ Health 1985;11:397-407.

2. Pearce N, Reif JS. Epidemiologic studies of cancer in agricultural workers. Am J Ind Med 1990;18:133-48.

3. Blair A, Zahm SH. Cancer among farmers. Occup Med 1991; 6:335-54.

4. Blair A, Hoar Zahm S, Pearce NE, Heineman EF, Fraumeni JF Jr. Clues to cancer etiology from studies of farmers. Scand J Work Environ Health 1992;18:209 — 15.

5. Wiklund K, Holm L-E. Trends in cancer risks among Swedish agricultural workers. JNCI 1986;77:657-64.

6. Olsen JH, Jensen OM. Occupation and risk of cancer in Denmark: an analysis of 93810 cases, 1970-1979. Scand J Work Environ Health 1987;13 suppl 1:1-91.

7. Milham S Jr. Occupational mortality in Washington state, 1950-1979. Cincinnati (OH): National Institute for Occupational Safety and Health (NIOSH), 1983. DHHS NIOSH publication, no 83-116.

8. Faustino A, Forastiere F, di Betta L, Magliola EM, Perucci CA. Cohort study of mortality among farmers and agricultural workers. Med Lav 1993;84:31 - 41 .

9. Lynge E, Thygesen L. Occupational cancer in Denmark: cancer incidence in the 1970 census population. Scand J Work Environ Health 1990;16 supp1 2:1-35.

10. Borgan J-K, Kristofersen LB. Mortality by occupation and socio-economic group in Norway 1970-1980. Oslo: Central Bureau of Statistics of Norway, 1986. Report vol 86/56.

11. Doll R. Urban and rural factors in the aetiology of cancer. Int $J$ Cancer 1991;47:803-10.

12. Central Bureau of Statistics. Population and housing census 1970, volume II: industry, occupation, working hours etc. Oslo: Central Bureau of Statistics of Norway, 1975.

13. Lynge E. Occupational mortality and cancer analysis. Public Health Rev 1992;99-116.

14. Burmeister LF. Cancer in Iowa farmers: recent results. Am J Ind Med 1990;18:295-301.

15. Cantor KP, Blair A, Everett G, Gibson R, Burmeister LF, Brown LM, et al. Pesticides and other agricultural risk factors for non-Hodgkin's lymphoma among men in Iowa and Minnesota. Cancer Res 1992;52:2447-55.

16. Zahm SH, Weisenburger DD, Saal RC, Vaught JB, Babbitt PA, Blair A. The role of agricultural pesticide use in the development of non-Hodgkin's lymphoma in women. Arch Environ Health 1993;48:353-8. 
17. Linet MS, Malker HSR, McLaughlin JK, Weiner JA, Blot WJ, Ericsson JLE, et al. Non-Hodgkin's lymphoma and occupation in Sweden: a registry based analysis. Br J Ind Med 1993; $50: 79-84$

18. Schuman LM, Choi NW, Gullen WH. Relationship of central nervous system neoplasms to Toxoplasma gondii infection. Am J Public Health 1967;57:848 - 56

19. Ryan P, Hurley SF, Johnson AM, Salzberg M, Lee MW, North JB, et al. Tumours of the brain and presence of antibodies to Toxoplasma gondii. Int J Epidemiol 1993;22:412-9.

20. Brunborg $\mathrm{H}$, Kravdal $\varnothing$. Fertility by birth order in Norway: a register based analysis. Oslo-Kongsvinger: Central Bureau of Statistics of Norway, 1986. Report 86/27.

21. World Health Organization (WHO). Manual of the international statistical classification of diseases, injuries and causes of death, 7th revision. Geneva: WHO, 1957.

22. American Cancer Society. Manual of tumor nomenclature and coding, 1968 edition. Chicago (IL): American Cancer Society Inc, 1968.

23. Cancer Registry of Norway. The incidence of cancer in Norway 1982-86. Oslo: Cancer Registry of Norway, 1989.

24. International Agency for Research on Cancer (IARC). Alcohol drinking. Lyon: IARC, 1988:252 - 9. IARC monographs on the evaluation of the carcinogenic risk of chemicals to humans, vol 44.

25. International Agency for Research on Cancer (IARC). Tobacco smoking. Lyon: IARC, 1986:309-14. IARC monographs on the evaluation of the carcinogenic risk of chemicals to humans, vol 38 .

26. Preston DL, Lubin JH, Pierce DA, McConney ME. Epicure, Seattle (WA): Hirosoft International Corporation, 1993.

27. Haenszel W, Loveland DB, Sirken MG. Lung cancer mortality as related to residence and smoking histories I: white males. JNCI 1962;28:947-1001.

28. Miettinen OS. Proportion of disease caused or prevented by a given exposure, trait or intervention. Am J Epidemiol 1974; $99: 325-32$

29. Axelson $O$. Aspects of confounding and effect modification in the assessment of occupational cancer risk. J Toxicol Environ Health 1980;6:1127-31.

30. Rønneberg A, Lund KE, Hafstad A. Lifetime smoking habits among Norwegian men and women born between 1890 and 1974. Int J Epidemiol 1994;23:267-76.

31. Vatten L, Almås R. Røkeadferd i landbruksbefolkningen [Smoking behavior in the agricultural population]. Tidsskr Nor Legeforen 1986;106:1666-8.

32. Central Bureau of Statistics of Norway. Survey of level of living 1991. Oslo-Kongsvinger: Central Bureau of Statistics of Norway, 1992.

33. Eriksson M, Hardell L, Malker H, Weiner J. Malignant lymphoproliferative diseases in occupations with potential exposure to phenoxyacetic acids or dioxins: a register-based study. An J Ind Med 1992;22:305-12.

34. Pottern LM, Heineman EF, Olsen JH, Raffn E, Blair A. Multiple myeloma among Danish women: employment history and workplace exposures. Cancer Causes Control 1992;3:42732.

35. Zahl SH, Blair A, Weisenburger DD. Sex differences in the risk of multiple myeloma associated with agriculture. $\mathrm{Br} J$ Ind Med 1992;49:815-6.

36. Blair A, Dosemeci M, Heineman EF. Cancer and other causes of death among male and female farmers from 23 states. Am J Ind Med 1993;23:729-42.

37. Franceschi S, Barbona F, Bidoli E, Guarneri S, Serraino D,
Talamini $\mathrm{R}$, et al. Cancer risk in farmers: results from a multisite case-control study in north-eastern Italy. Int $\mathrm{J}$ Cancer $1993 ; 53: 740-5$.

38. Figgs LW, Dosemeci M, Blair A. Risk of multiple myeloma by occupation and industry among men and women: a 24-state death certificate study. J Occup Med 1994;36:1210 - 21

39. Linet MS, McLaughlin JK, Malker HSR, Chow W-H, Weiner JA, Stone BJ. Occupation and hematopoietic and lymphoproliferative malignancies among women: a linked registry study. J Occup Med 1994;36:1187-98.

40. Burmeister LF, Everett GD, van Lier SF, Isacson P. Selected cancer mortality and farm practices in Iowa. Am J Epidemiol 1983;118:72-7.

41. Cantor KP, Blair A. Farming and mortality from multiple myeloma: a case-control study with the use of death certificates. JNCI 1984;72:251-5.

42. Morris PD, Koepsell TD, Daling JR, Taylor JW, Lyon JL, Swanson GM, et al. Toxic substance exposure and multiple myeloma: a case-control study. JNCI 1986;76:987-94.

43. Bofetta P, Stellman SD, Garfinkel L. A case-control study of multiple myeloma nested in the American Cancer Society prospective study. Int J Cancer 1989;43:554-9.

44. Lindqvist C, Teppo L. Epidemiological evaluation of sunlight as a risk factor of lip cancer. Br J Cancer 1978;37:983-9.

45. Lindqvist C. Risk factors in lip cancer: a questionnaire study. Am J Epidemiol 1979;109:521-30.

46. Reif J, Pearce N, Fraser J. Cancer risks in New Zealand farmers. Int J Epidemiol 1989;18:768 - 74.

47. Penn I. Immunosuppression and skin cancer. Clin Plast Surg $1980 ; 7: 361-8$

48. Kinlen L, Doll R, Peto J. The incidence of tumors in human transplant recipients. Transplant Proc 1983;15:1039-42.

49. Bjørlo B, Loen A, Ouren E. Drifts- og yrkesstrukturen i jordbruket i 1985/86 [Types of farming and the occupational structure in farming: reports from the Central Bureau of Statistics of Norway]. Oslo-Kongsvinger: Central Bureau of Statistics of Norway, 1988.

50. Whitaker CJ, Lee WR, Downes JE. Squamous cell skin cancer in the northwest of England, 1967-69, and its relation to occupations. Br J Ind Med 1979;36:43-51.

51. Lee JAH. Melanoma. In: Schottenfeld D, Fraumeni JF Jr, editors. Cancer epidemiology and prevention. Philadelphia (PA): WB Saunders, 1982:984 95.

52. Silverman DT, McLaughlin JK, Malker HSR, Weiner JA, Ericson JLE. Bladder cancer and occupation among Swedish women. Am J Ind Med 1989;16:239-40.

53. Institute for Epidemiologic Cancer Research. Forekomst av kreftsykdommer i Norges kommuner [Occurrence of cancer in Norwegian municipalities]. Oslo: The Cancer Registry of Norway, 1993

54. Brownson RC, Reif JS, Chang JC, Davis JR. An analysis of occupational risks for brain cancer. Am J Public Health 1990; $80: 169-72$

55. Musicco M, Filippini G, Bordo BM, Melotto A, Morello G, Berrino F. Gliomas and occupational exposure to carcinogens: case-control study. Am J Epidemiol 1982;116:782-90.

56. Musicco M, Sant M, Molinari S, Filippini G, Gatta G, Berrino F. A case-control study of brain gliomas and occupational exposure to chemical carcinogens: the risk to farmers. Am J Epidemiol 1988;128:778-85.

57. Mellemgaard A, Engholm G, Lynge E. High and low risk groups for cancer of colon and rectum in Denmark: multiplicative Poisson models applied to register linkage data. J Epidemiol Community Health 1988;42:249—56. 
58. Central Bureau of Statistics of Norway. Survey of consumer expenditure 1973. Oslo: Central Bureau of Statistics of Norway, 1975.

59. Morrison H, Savitz D, Semenciw R, Hulka B, Mao Y, Morison D, et al. Farming and prostate cancer mortality. Am J Epidemiol 1993;137:270—80.

60. Wiklund K, Dich J, Holm L-E. Testicular cancer among agricultural workers and licensed pesticide applicators in Sweden [letter]. Scand J Work Environ Health 1986;12:630-1.

61. Kristensen P, Andersen A. A cohort study on cancer incidence in offspring of mate printing workers. Epidemiology 1992 $3: 6-10$.

62. Frøslie A. Utviklingstrekk i godkjenningsbetingelsene for plantevernmidler [Trends in criteria for approval of pesticides]. In: Norwegian Plant Protection Institute: the struggle against pests, plant protection in Norway 100 years $1891-$ 1991. Ås (Norway): Norwegian Plant Protection Institute, 1991:65-71.

Received for publication: 21 March 1995 